\section{Cartoon Editorial}

\section{OPEN ACCESS}

Received: Jun 4, 2019

Accepted: Jun 5, 2019

Address for Correspondence:

Min Suk Chung, MD, PhD

Department of Anatomy, Ajou University

School of Medicine, 164 World Cup-ro,

Yeongtong-gu, Suwon 16499, Republic of Korea.

E-mail: dissect@ajou.ac.kr

C 2019 The Korean Academy of Medical

Sciences.

This is an Open Access article distributed under the terms of the Creative Commons Attribution Non-Commercial License (https:// creativecommons.org/licenses/by-nc/4.0/) which permits unrestricted non-commercial use, distribution, and reproduction in any

medium, provided the original work is properly cited.

ORCID iDs

Min Suk Chung (D)

https://orcid.org/0000-0002-0527-9763

\section{Disclosure}

The author has no potential conflicts of interest to disclose.

\section{Sunshine Policy for Internet Gaming}

\section{Min Suk Chung $\mathbb{1}$}

Department of Anatomy, Ajou University School of Medicine, Suwon, Korea

- See the article "A Comparison of Risk and Protective Factors for Excessive Internet Game Play between Koreans in Korea and Immigrant Koreans in the United States" in volume 34, number 23, e162.

(D)

Sunshine policy for internet gaming

Adolescents' excessive internet gaming can be relieved by the sunshine policy.

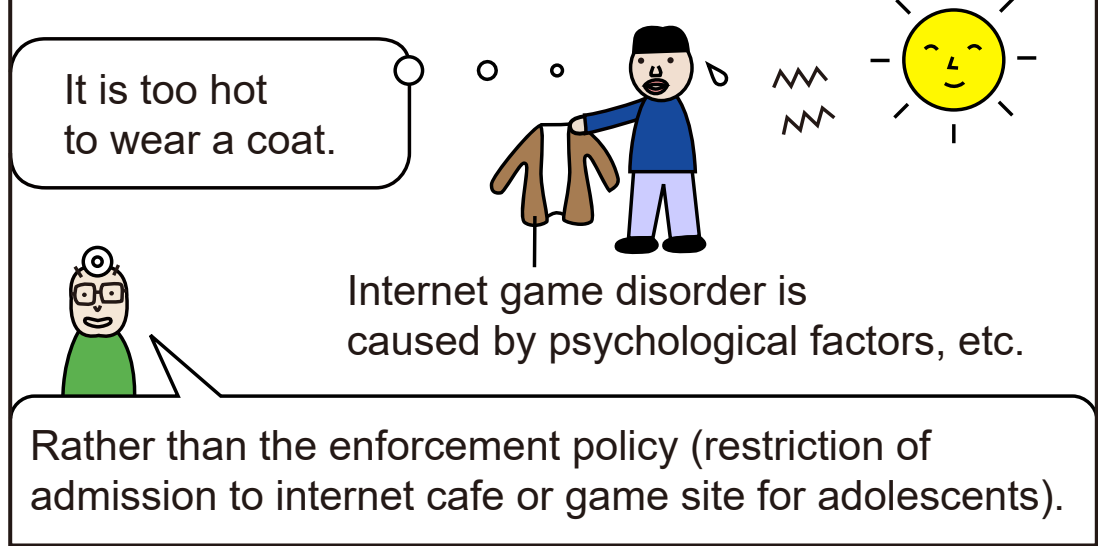

The sunshine effect is different according to groups.
Koreans in

Korea
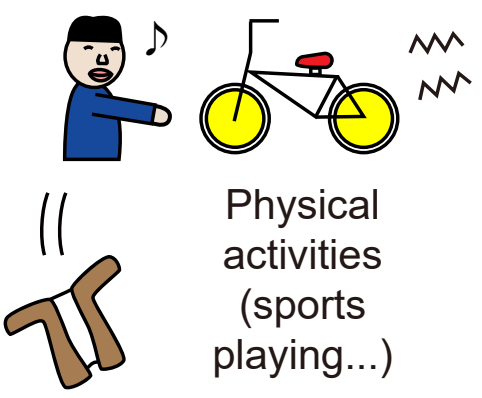

Physical activities

(sports

playing...)
Koreans in United States
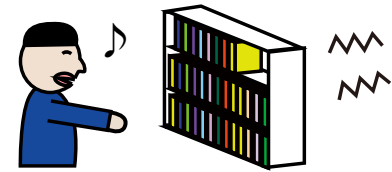

Media activities

(book

reading...) 